\title{
Effect of the Short Day Treatment on the Growth Periodical Variation of Osmotic Value in Soybean Plants*
}

\author{
by Shosuke KAKU**
}

\section{賀来章輔：ダイブの生育週期的渗透価变化に己文ず短日処理の影響}

\section{Received February 21, 1955}

The effect of short day treatment on flowering was already studied by many investigators. According to Sō et $\mathrm{al}^{6}$ ) the increase of cell sap concentration and reducing sugar was observed in a plant of short day nature when it was laid under short day photoperiod. The present author took up the problem concerning the influences of short day treatment on osmotic values, as no report could be found on this question. In the previous paper ${ }^{3}$ he stated that the variation of osmotic value of a plant was induced firstly by growth periodicity and secondarily by climatic factors. The short day treatment accelerates the growth period of a short day plant and the plant become to grow in unnatural seasonal conditions. So that the studies of a short day treated plant will also be valuable for solving the problem of the periodical variation of osmotic value of a plant.

\section{Material and Method}

Soybean (Glycine hispida Max.) of a late season variety "Kyushu Autum No. 2 " were sown on May 14, 1953. The seedlings were planted in pots. The soil moisture in the pots was kept at $80 \%$ of the saturated water capacity. The experimental plots were divided into three as follows; (A) Control plot of natural day-length, (B) Late treated short day plot, the treatment was commenced on July 5, 43rd day after germination, (C) Early treated short day plot, the treatment was commenced on June 1, 8th day after germination. The treatment was carried out as follows: the daily light period was shortened to 10 hours before podding. The osmotic value of upper epidermal cells of leaves was measured at incipient plasmolysis in $\mathrm{KNO}_{3}$ solution. The values are the means of five leaves representing vertical position of the plant.

\section{Experimental Results}

(1) Shortening effect on growth periods The flowering period arrived in (B) 15 days and in (C) 39 days earlier than the control (A) (Table 1). In (B) and (C)

\footnotetext{
* Problem of physical and physiological dryness. Rep. 17 by Y. Fukuda; 科助成研究

** Shimonoseki Commercial Upper Secondary School. 下関商業高等学校
} 
podding began only $4 \sim 5$ days after the commencement of flowering, while in control (A) it took place three weeks after. The short day treatment accelerated not only flowering but also podding. Bortwhick \& Parker1) stated that matured leaves are more sensible to photoperiodic stimulus than the younger ones. Reckoning from the day of treatment, (B) flowered 11 days earlier than (C). So it may also be said that a matured plant are more susceptible to photoperiodic stimulus than an immatured one.

Table 1. Effect of the shortening of growth by short day treatment

\begin{tabular}{|c|c|c|c|c|c|c|c|c|c|}
\hline \multirow{2}{*}{$\begin{array}{c}\text { Experimental } \\
\text { plot }\end{array}$} & \multicolumn{2}{|c|}{$\begin{array}{l}\text { Beginning of short } \\
\text { day treatment }\end{array}$} & \multicolumn{5}{|c|}{ Beginning of flowering } & \multirow{2}{*}{$\begin{array}{c}\text { Days from } \\
\text { flowering } \\
\text { to } \\
\text { podding }\end{array}$} & \multirow{2}{*}{$\begin{array}{c}\text { Diff. } \\
(\mathrm{A}-\mathrm{B}, \mathrm{C})\end{array}$} \\
\hline & Date & $\begin{array}{l}\text { Days after } \\
\text { germination }\end{array}$ & Date & $\begin{array}{l}\text { Days after } \\
\text { germination }\end{array}$ & $\begin{array}{c}\text { Diff. } \\
(\mathrm{A}-\mathrm{B} \\
\mathrm{C})\end{array}$ & $\begin{array}{l}\text { Days after } \\
\text { short day } \\
\text { treatment }\end{array}$ & Diff. & & \\
\hline Natural (A) & & & Aug. 8 & 77th day & & & & 21 & \\
\hline $\begin{array}{l}\text { Late treated } \\
\text { short day (B) }\end{array}$ & Jul. 5 & 4.3rd day & Jul. 24 & 62 nd day & 15 & 19 & & 5 & 16 \\
\hline $\begin{array}{l}\text { Early treated } \\
\text { short day (C) }\end{array}$ & Jun. 1 & 8th day & Jul. 1 & 38 th day & 39 & 30 & 11 & 4 & 17 \\
\hline
\end{tabular}

(2) Restraint of stem growth. Dwarfishness can be seem clearly in (B) but

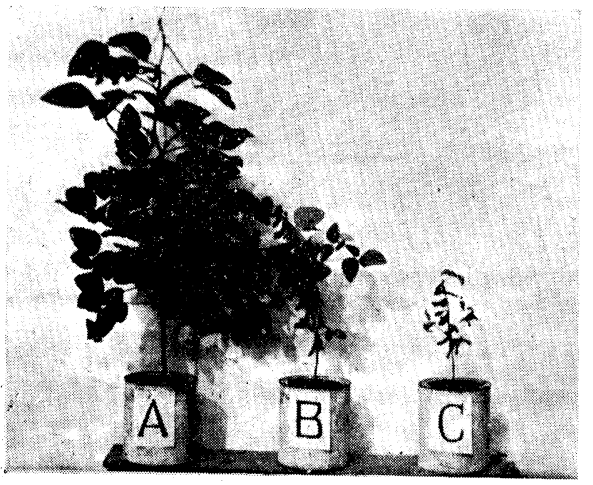

Fig. 1. Comparision of the apperance of soybean plants whose short day treatment began at various times (Phothographed on Sept. 20, 1953).

A) Natural day-length plot;

B) Late treated short day plot;

C) Early treated short day plot is extreme in (C) (Figs. $1 \&$ 2). The similar phenomenon was already reported by many authors who mentioned that dwarfishness occured as the result of the precocious differentiation of reproductive organ formation (Taguchi ${ }^{7)}$. The short day treatment on (C) began on June 1 , but for 25 days no sympton of the restraint of stem elongation was observed (Fig. 2). But the restraint was observed on (B) 5 days after the commencement of the treatment. The restraint appeared in (C) 5 days and in (B) 10 days before flowering. The short day treatment was more effective in accelerating flowering than commencing the restraint of stem elongation.

\section{(3) Common variation of the osmotic values according to the growth periodi-} city The osmotic values of all plants belonging to (A), (B) and (C) increased gradually as the plants grew and they descended somewhat at flowering and ascended again at podding. The maximum value appeared at ripening season. This common tendency appeared under different climatic conditions. No peculiar seasonal 


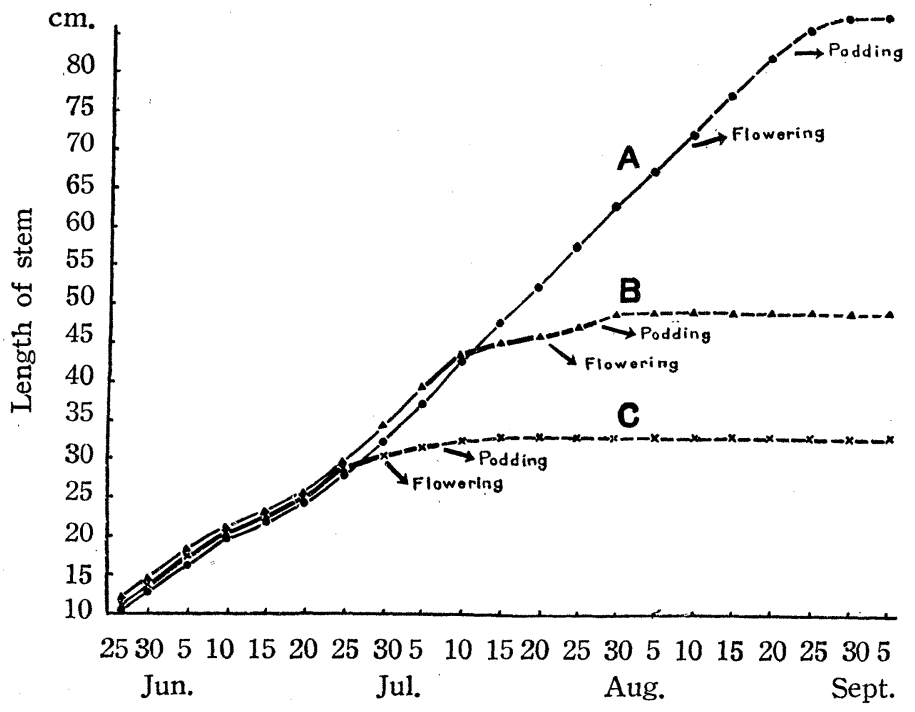

Fig. 2. Growth curve of stem of soybean plants whose short day treatment began at various times

A) Natural day-length plot; B) Late treated short day plot (commenced on Jul. 5. 1953); C) Early treated short day plot (commenced on Jun. 1, 1953)

Thick lines indicate the periods of short day treatment.

Broken lines indicate the period after flowering.

change of osmotic values was observed by the short day treatment.

Table 2. Osmotic value at the same growth period of plants whose short day treatment began at various times

\begin{tabular}{|c|c|c|c|c|c|c|c|c|c|c|}
\hline \multirow{2}{*}{$\begin{array}{c}\text { Experimental } \\
\text { plot }\end{array}$} & \multicolumn{3}{|c|}{ Flowering period } & \multicolumn{3}{|c|}{ Podding period } & \multicolumn{3}{|c|}{ Ripening period } & \multirow{2}{*}{$\begin{array}{c}\text { Number } \\
\text { of ripe } \\
\text { pod }\end{array}$} \\
\hline & Date & $\begin{array}{c}\text { Osmotic } \\
\text { value } \\
\left(\mathrm{KNO}_{3} \mathrm{~mol}\right)\end{array}$ & $\begin{array}{l}\text { Diff. } \\
\text { (A-B, } \\
\text { C) }\end{array}$ & Date & $\begin{array}{c}\text { Osmotic } \\
\text { value } \\
\left(\mathrm{KNO}_{3} \mathrm{~mol}\right)\end{array}$ & $\begin{array}{c}\text { Diff. } \\
(\mathrm{A}-\mathrm{B}, \\
\mathrm{C})\end{array}$ & Date & $\begin{array}{c}\text { Osmotic } \\
\text { value } \\
\left(\mathrm{KNO}_{3} \mathrm{~mol}\right)\end{array}$ & $\mid \begin{array}{c}\text { Diff. } \\
(\mathrm{A}-\mathrm{B} \\
\mathrm{C})\end{array}$ & \\
\hline Natural (A) & Aug. 7 & 0.31 & & $\begin{array}{r}\text { Aug. } \\
28\end{array}$ & 0.40 & & $\begin{array}{c}\text { Sept. } \\
22\end{array}$ & 0.45 & & 55 \\
\hline $\begin{array}{l}\text { Late treated } \\
\text { short day (B) }\end{array}$ & Jul. 22 & 0.27 & -0.04 & Jul. 28 & 0.33 & -0.07 & $\underset{22}{\text { Aug. }}$ & 0.35 & -0.10 & 40 \\
\hline $\begin{array}{l}\text { Early treated } \\
\text { short day (C) }\end{array}$ & Jul. 1 & 0.24 & -0.07 & Jul. 7 & 0.28 & -0.12 & Jul. 28 & 0.31 & -0.14 & 18 \\
\hline
\end{tabular}

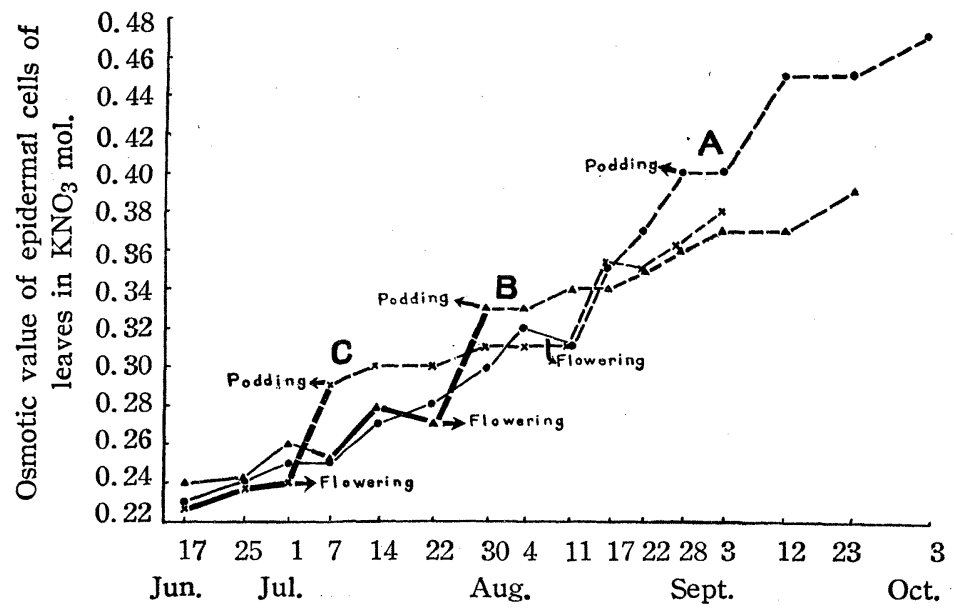

Fig. 3. Variation of the osmotic value in soybean plants whose short day treatment began at various times

A) Natural day-length plot; B) Late treated short day plot;

C) Early treated short day plot

Thick lines indicate the period of short day treatment.

Broken lines indicate the period after flowering. 
(4) Lowering effect on osmotic value at the same growth periods Table 2 and Fig. 3 show the osmotic values of the plants of (A), (B) and (C) at the same growth periods. In Fig. 3 climate seems not to modify the growth periodical variations. The values of (C) are the lowest and those of (A) are the highest at each stages (Table 2). At each growth period (flowering, podding and ripening) the osmotic value is low if the period is attained in early age. In spite of their low osmotic value, the treated plants bore pods which contained normal seeds though the yield was less corresponding to the restraint of growth.

\section{Discussion}

The coming of flowering period is a definite physiological phenomenon wherein osmotic value temporarily lowers. At this cardinal point the osmotic value, however, differs in each plot: the value is lower in precocious plants and higher in late matured ones (Table 2). The osmotic values depend upon the length of duration of vegetative growth from germination till flowering. And the differences of the values among three plots are kept during the rest of their lives. Furthermore, these differences still increase at podding and then at ripening, as the growth stages advance. As short day treatment shortens growth periods, the treated plants become to posses lower osmotic value, in proportion to the duration of the treatment. Namely, short day treatment does not affect osmotic value which increases with the progress of vegetative growth. It can be said, from the opposite view point, that the growth periodical variation occurs indipendent of the comparatively low osmotic values in the treated plants. The continuance of short day treatment accelerates the differentiation of reproductive organ formation even at the diminished vegetative growth and osmotic value.

\section{Conclusion}

The effect of short day treatment accelerates the differentiation of reproductive organ formation and causes the shortening of growth periodicity. The osmotic value of a plant varies according to the length of growth duration: the normal one whose growing duration is longest has the highest value, and a heavily treated one with the shortest growth duration has the lowest. The degree of osmotic ascension caused by the aging is the function of the age of vegetative growth and is not influenced by the maturation caused by the differentiation of reproductive organs. The growth periodical variation of osmotic value regularly appears indipendently of both the length of growth duration and the growing season.

The writer is indebted to Mr. Yoshio Furutani of Kyushu Agricultural Experimental Station for his kindness in supplying material for this study. 


\section{References}

1. Bortwhick, H. A. \& Parker, M. W. Bot. Gaz. 100: 249 (1938), ibidem 101: 806 (1940). 2. Fukuda, Y. \& Kaku, S. Bot. Mag. Tokyo 65: 267 (1952). 3. Kaku, S. Bot. Mag. Tokyo 68: 114 (1955). 4. Lang, A. Ann. Rev. Pl. physiology 3: 265 (1952). 5. Murneek, A. E. Vernalization and Photoperiodism p. 39 (1948). 6. Sō, M., Kobayashi, Y. \& Hîrose, D. Agric. \& Hortic. 2 : 117 (1927). (Japanese) 7. Taguchi, R. Seitaigaku gaisetsu p. 156 (1952). (Japanese)

抄錄

\section{紅藻 Iridophycus Flaccidum (Irideae laminarioides)}

の光合成による $\mathrm{C}^{14} \mathrm{O}_{2}$ の同化

[Beans, R.C. and Hassid, W.Z.: Assimilation of $\mathrm{C}^{14} \mathrm{O}_{2}$ by photosynthesizing Red

Alga, Iridophycus Flaccidum., J. Biol. Chem., 212: 411 425 (1955)]

陸上植物では D-ブドウ糖と D-果糖が単糖類 としては広く存在し, 蔴糖, 澱粉, 七ルローズ, フ ラクトザンがこれらの主な寡糖類文び多糖類であ る。多くの海藻では陸上植物の有している様な岸 水化物は全然有していないか, 有していてす比較 的少量で, マンニトル, フロリドサイド（ガラク トースのグリセリン・エステル）グリセリンマン ノサイド, 及びマンノウロン酸, L-フコーズ, Dガラクトース残基から成る多糖類が主な炭水化物 成分である。かように, 陸上植物と海藻では, そ れらの主な炭水化物成分が異つているので，光合 成に於いても，炭素が㟶水化物を生成する過程が 異つているか否かを, 紅藻 Iridophycus flaccidum で検してみた。

材料は California の Moss Beach の tidal rocks で採集した果胞子のできてない生長期にあ る葉状体（同地で採集した同材料については，主 な炭水化物成分である粘物質即ちガラクタンの硫 酸エステル仅びフロリドサイドの構造等に関し, 1933年以来 Hassid の多くの報告がある。） 6〜 $24 \mathrm{~cm}^{3}, 0.25 \sim 1.0 \mathrm{gm}$ の切片にしたむのを用い。
それを $\mathrm{C}^{4} \mathrm{O}_{2}$ を導き入れられる Chamber を有 する光合成装置中に置いて実験を行つた。

光合成の最初の 8 秒間にグリセリン酸粼酸セド へプチュロース燐酸, 果糖一燐酸, ブドウ糖一燐 酸が, 8〜15 秒の間に, $\alpha$-グリセリン粼酸ウリジン 二燐酸ブドブ糖ガ， $15 〜 30$ 秒間にウリジン=燐 酸ガラクトース,フロリドサイドが labelされ，そ の他フロリドサイド粦酸, グッシン, セッン, ア ラニン, グリセリン酸, グルコン酸, リンゴ酸, グルタミン酸, アスパラギン酸も label された。 C14 の蓄積の最む多いむのはフロリドサィドであ つた。これのガラクトースとグリセリンのC14 量 の比は 4 回の実験においてすべて, 略 2 に近い值 を示した。I. faccidum の光合成の初期の段階の 生成物は, クロレラや高等植物 (Benson et al and Calvin 1950 1952) の場合と同じであり, それらの形成の速度も同様であつた。文,フロリ ドサイドは高等植物の䓞糖に相当し, この紅藻の 主な貯蔵炭水化物であると思われる。

（野村一郎） 